\title{
Determination and Comparison of Non-essential and Essential Elements in Different Species of Fish Available in Omani Markets by Using Inductively Coupled Plasma-optical Emission Spectrometry
}

\section{Issa Al-Amri ${ }^{1 *}$, Isam Kadim ${ }^{1}$, Abdulaziz AlKindi ${ }^{1}$, Ahmed Al-Harrasi ${ }^{1}$, Khadija Al-Hosni ${ }^{1}$, Aiysha Al-Kiymi ${ }^{1}$, Anwar Al-Amri ${ }^{1}$, Muzna Al-Salehi ${ }^{1}$, Fazal Mabood ${ }^{1}$, Ahmed Hamaed ${ }^{1}$, Saud M Al Jufaili ${ }^{3}$, Samera Khalaf ${ }^{2}$ and Mohamed Al-Omairi ${ }^{2}$}

${ }^{1}$ Department of Biological Sciences and Chemistry, College of Arts and Sciences, University of Nizwa, Sultanate of Oman, Oman

${ }^{2}$ Natural and Medical Sciences Research Center, University of Nizwa, Sultanate of Oman, Oman

${ }^{3}$ Department of Marine Science and Fisheries, College of Agricultural and Marine Sciences, Sultan Qaboos University, Muscat, Sultanate of Oman, Oman

*Corresponding Author: Issa Al-Amri, Department of Biological Sciences and Chemistry, College of Arts and Sciences, University of Nizwa, Sultanate of Oman.
Received: November 11, 2020

Published: December 30, 2020

(C) All rights are reserved by Issa Al-Amri., et al.

\section{Abstract}

In this study an ICP-OES (inductively coupled plasma-optical emission spectrometry) was used to investigate the concentration levels of both essential and non-essential elements in 70 edible portion of fish samples representing 11 different species of fish collected from Omani markets. Sample preparation via microwave digestion were analyzed, using ICP-OES for seven non-essential elements [Arsenic (As), cadmium (Cd), nickel (Ni), lead (Ph), titanium (Ti), chromium (Cr) and mercury (Hg)] and seven essential elements [iron (Fe), copper ( $\mathrm{Cu}$ ), zinc $(\mathrm{Zn})$, phosphorus (P), calcium (Ca), selenium (Se), and magnesium (Mg)]. A comparison of the results for the concentration of $\mathrm{Cd}, \mathrm{Ni}, \mathrm{Pb}, \mathrm{Ti}, \mathrm{Cu}$ and $\mathrm{Fe}$ elements between the species of fish showed that there was significant $(\mathrm{P}<$ 0.05) difference in concentrations. Tissue samples from Seriola dumerili and Xiphias gladius tissues contained significantly (P < 0.05) higher levels of $\mathrm{Cd}$, while Lutjanus argentimaculatus and Parastromateus niger samples had significantly (P < 0.05) higher levels of $\mathrm{Ni}$ than those from other fish species. The levels $\mathrm{Pb}$ found in the tissues of Merluccius bilinearis, and Lethrinus nebulosus fish were significantly $(\mathrm{P}<0.05)$ higher than other fish species. Further, Lethrinus nebulosus and seriola dumerili tissue samples contained significantly $(\mathrm{P}<0.05)$ higher concentrations of Ti. The concentrations of $\mathrm{Ni}$ and $\mathrm{Pb}$ were found higher than the maximum permissible limits in certain fish species samples for human consumption. The results indicated that the edible portion contained significantly (P $<0.05$ ) higher levels of $\mathrm{Cu}$ in Seriola dumerili species and Fe elements in Ocyurus chrysurus and Pagellus affinis than other fish species. This study concluded that $\mathrm{Cd}, \mathrm{Ni}, \mathrm{Pb}, \mathrm{Ti}, \mathrm{Cu}$ and Fe elements were species-dependent.

Keywords: Non-essential Element; Essential-element; Tissue; Inductively Coupled Plasma-optical Emission Spectrometry; Heavy Metals; Fish; Oman

\section{Introduction}

Arsenic (As), cadmium (Cd), nickel (Ni), lead $(\mathrm{Ph})$, titanium (Ti), chromium $(\mathrm{Cr})$ and mercury $(\mathrm{Hg}$ ) elements are considered as non-essential elements because they do not have a biological role, and are toxic for the health of humans. On the other hand, iron (Fe), copper (Cu), zinc (Zn), phosphorus (P), calcium (Ca), selenium (Se), and magnesium $(\mathrm{Mg})$ are considered as essential elements due to their important roles in the physiological functions of the human body [1-4]. Deficiency of essential elements may cause inappropri-

Citation: Issa Al-Amri., et al. "Determination and Comparison of Non-essential and Essential Elements in Different Species of Fish Available in Omani Markets by Using Inductively Coupled Plasma-optical Emission Spectrometry". Acta Scientific Nutritional Health 5.1 (2021): 60-73. 
ate metabolic functions of enzymes and can results in physiological body failures, and long-lasting diseases [5]. Fish like another organisms need these elements, but if they exceed the metabolic requirement they become accumulated in their tissues, because most of these elements are non-biodegrade [6]. The heavy metals are known as environmental pollutants and characterized by their atomic weights $[7,8]$ and their affinity with biological human tissues $[9,10]$. Non-essential elements including $\mathrm{As}, \mathrm{Cd}, \mathrm{Ni}, \mathrm{Pb}, \mathrm{Ti}$, $\mathrm{Cr}$, and $\mathrm{Hg}$ due to its toxicity although at low levels is hazardous for human health because due to bioaccumulation in some foodstuffs [11-14]. The heavy elements may be taken up by various fish species and accumulates in their body organs from food, water, or sediments for their body metabolism [15]. Even at low levels of concentration, non-essential elements can be dangerous for fish consumers' health and long-term intake may result in the accumulation of toxic heavy metals in human body [16]. It has also been reported that health hazardous effects of trace elements occur when the biological system in humans are no longer able to counter uptake, which affects the physiological and histopathological functions of body organs [17-20].

Although, fish products are among the most popular of the human diet [21], their products might be contaminated by toxic elements and may be dangerous for human health due to bioaccumulation in the human body. Fish species have the ability to bio-accumulate heavy metals in their tissues through adsorption and absorption via gill surface [22-26]. Areas with higher traffic and agricultural activities have reported high levels of heavy metals [25,27]. Therefore, contaminated fish are unfit for human consumption due to high concentrations of heavy metals in their products [3,28-32]. The toxic trace elements may cause kidney failure, liver damage, and cardiovascular diseases, therefore, to protect people's health, levels of heavy metals should be assessed by using chemical biomonitoring as early indicators of biological effects [25]. It has been reported that certain fish species may be used as a bio-indicator of specific trace elements compared to others [3336]. Heavy metal contamination in fish maybe also be due to sediment from bottom dwelling and bottom feeding fish. Many other factors like reproductive cycle, sex, size, age, swimming patterns, living environment and feeding behavior may affect contamination of heavy metals in fish [37-41]. It has been stated that harmful trace elements are linked to increased consumption of fish products with the growing concern of their nutritional and therapeutic benefits [26].

\section{Aim of the Study}

Due to hazardous health effects because of the contamination of heavy metals in fish meats, this study was aimed to characterize heavy metal concentration in different fish species available in local markets of Oman. Concentration of seven non-essential elements including $\mathrm{As}, \mathrm{Cd}, \mathrm{Ni}, \mathrm{Pb}, \mathrm{Tl}, \mathrm{Cr}$ and $\mathrm{Hg}$ and seven essential elements including $\mathrm{Cu}, \mathrm{Fe}, \mathrm{Zn}, \mathrm{P}, \mathrm{Ca}$, Se, and $\mathrm{Mg}$ were carried out in 70 fish samples using ICP-OES.

\section{Materials and Methods}

Fish species samples

A total of 42 fish samples representing different species were purchased from local markets from the Nizwa city in Sultanate of Oman in the month of March 2020. Samples details are described in Table 1. The 14 fish species vary naturally in size. Silver Hake, Aqumarine and Premium fillets were frozen and imported fillets, while the remaining species were fresh. After collection the samples were put in polyethylene bags and transported to the University of Nizwa laboratory in an ice box for investigation. Then clean forceps and scissors were used to dissect the fish samples after they had been classified into demersal or pelagic fish.

\section{Preparation of samples}

Approximately $300 \mathrm{~g}$ of flesh from each species of fish sample was cut in small pieces with a clean knives, and dried using Memmert UF10m, Germany oven at $80^{\circ} \mathrm{C}$ until a constant weight was obtained. The dried fish samples were allowed to cool and then ground (Grinder Panasonic, brand MX- AC210S, India) into fine powder, kept in labeled containers and stored in desiccators in the dark until digestion. Mineralization was accomplished using ultra-microwave-assisted acid digestion system (Single Reaction Chamber Microwave Digestion System, Ultrawave, Milestone, USA). Briefly, $2 \mathrm{~mL}$ of $\mathrm{H}_{2} \mathrm{O}_{2}(30 \% \mathrm{v} / \mathrm{v})$ and $6 \mathrm{~mL}$ of $\mathrm{HNO}_{3}(68 \% \mathrm{v} / \mathrm{v}$ ) (all analytical grade from company MRS Scientific Limited, UK) was added to $0.8 \mathrm{~g}$ of each fish sample and the vessels were placed into the microwave digestion system. Fish samples digestion was achieved by heating up to $120^{\circ} \mathrm{C}$ for $25 \mathrm{~min}$, then increasing the temperature to $190^{\circ} \mathrm{C}$ for $35 \mathrm{~min}$ and then cooled down for $30 \mathrm{~min}$ to reach room temperature. The solution of each sample was then transferred into $50 \mathrm{~mL}$ volumetric flasks and were diluted to the mark by adding ultrapure water for subsequent analysis by ICP-OES. Each sample 
Determination and Comparison of Non-essential and Essential Elements in Different Species of Fish Available in Omani Markets by Using Inductively Coupled Plasma-optical Emission Spectrometry

\begin{tabular}{|c|c|c|c|}
\hline Number & $\begin{array}{c}\text { Commercial } \\
\text { name }\end{array}$ & Scientific name & Geolocation \\
\hline 1 & $\begin{array}{l}\text { Silver Hake } \\
\text { (Imported) }\end{array}$ & Merluccius bilinearis & Demersal \\
\hline 2 & Naiser fish & Ocyurus chrysurus & $\begin{array}{c}\text { reef- } \\
\text { associated }\end{array}$ \\
\hline 3 & Arabian Pandora & $\begin{array}{c}\text { Pagellus affinis } \\
\text { (Boulenger, 1887) }\end{array}$ & Demersal \\
\hline 4 & Aqumarine fillet & Merluccius bilinearis & Demersal \\
\hline 5 & $\begin{array}{l}\text { Brownspotted } \\
\text { Grouper }\end{array}$ & $\begin{array}{l}\text { Epinephelus } \\
\text { chlorostigma }\end{array}$ & $\begin{array}{c}\text { reef- } \\
\text { associated }\end{array}$ \\
\hline 6 & Premium fillet & Merluccius bilinearis & Demersal \\
\hline 7 & Skipjack Tuna & $\begin{array}{l}\text { Katsuwonus pelamis } \\
\text { (Linnaeus, 1758) }\end{array}$ & $\begin{array}{l}\text { Pelagic- } \\
\text { oceanic }\end{array}$ \\
\hline 8 & Sword fish & $\begin{array}{l}\text { Xiphias gladius } \\
\text { (Linnaeus, 1758) }\end{array}$ & $\begin{array}{l}\text { Pelagic- } \\
\text { oceanic }\end{array}$ \\
\hline 9 & $\begin{array}{l}\text { Mangrove } \\
\text { Snapper }\end{array}$ & $\begin{array}{l}\text { Lutjanus argentimacu- } \\
\text { latus (Forsskal, 1775) }\end{array}$ & $\begin{array}{c}\text { Reef- } \\
\text { associated }\end{array}$ \\
\hline 10 & Black pomfret & $\begin{array}{c}\text { Parastromateus niger } \\
\text { (Bloch, 1795) }\end{array}$ & $\begin{array}{c}\text { Reef- } \\
\text { associated }\end{array}$ \\
\hline 11 & Local Emperor & $\begin{array}{l}\text { Lethrinus nebulosus } \\
\text { (Forsskal, 1775) }\end{array}$ & $\begin{array}{c}\text { Reef- } \\
\text { associated }\end{array}$ \\
\hline 12 & $\begin{array}{l}\text { Spangled } \\
\text { Emperor }\end{array}$ & $\begin{array}{l}\text { Lethrinus nebulosus } \\
\text { (Forsskål, 1775) }\end{array}$ & $\begin{array}{c}\text { Reef- } \\
\text { associated }\end{array}$ \\
\hline 13 & $\begin{array}{c}\text { Greater } \\
\text { Amberjack }\end{array}$ & $\begin{array}{l}\text { Seriola dumerili } \\
\text { (Risso, 1810) }\end{array}$ & $\begin{array}{c}\text { Reef- } \\
\text { associated }\end{array}$ \\
\hline 14 & Indian Mackerel & $\begin{array}{c}\text { Rastrelliger kanagurta } \\
\text { (Cuvier, 1817) }\end{array}$ & Pelagic-neritic \\
\hline
\end{tabular}

Table 1: Commercial and scientific names and geolocations of fish species samples collected from the local markets in Oman.

was analyzed in triplicates using the Optima ${ }^{\mathrm{TM}} 8000$ ICP-OES by PerkinElmer, USA. Elemental standard solutions of $\mathrm{Hg}, \mathrm{Pb}, \mathrm{Cd}, \mathrm{As}$, $\mathrm{Ni}, \mathrm{Ti}, \mathrm{Cr}, \mathrm{Cu}, \mathrm{Zn}, \mathrm{Fe}, \mathrm{P}, \mathrm{Ca}$, Se and $\mathrm{Mg}$ ) (1000 mg L- ${ }^{1}$ ) were supplied by MRS Scientific Limited, UK and were used for building the standard calibration curve. The samples were analyzed by ICP-OES and the results were compared to a multi-element standard calibration curve to quantify the amount of each heavy metal analyzed in the digested solution of fish sample.

\section{Statistical analysis}

For all the data analysis the Microsoft Excel 365 and SPSS 16.0 were used to find the independent T-test. Differences at the $\mathrm{P}<$ 0.05 level was considered significant.

\section{Results and Discussion}

Fish is considered by many consumers as a highly nutritious food, therefore, many people consume fish due to its availability, flavor and palatability. The overall mean and range results from ICP-OES analysis for 14 elements (7 non-essential- and 7 essential elements) in different species of fish are shown in Tables 2 to 5 . All the heavy metal elements were almost detected in all edible portions of fish species with the exception of very few samples.

Non-essential elements

Analyses of all the fish species samples examined revealed the highest level of $\mathrm{Ni}$, followed by $\mathrm{Pb}$ as a non-essential element, with range values from 0.00 to $6.188 \mu / \mathrm{g}$ and from 0.00 to 13.2 $\mu / g$, respectively (Table 2). Overall pattern of distribution of nonessential elements as $\mathrm{Ni}>\mathrm{Pb}>\mathrm{Ti},>\mathrm{Cd}>\mathrm{Cr}>\mathrm{As}>\mathrm{Hg}$ for all the fish species. It was interesting to note that the Xiphias gladius and Seriola dumerili species had among the highest levels of $\mathrm{Cd}$, while Lutjanus argentimaculatus, and Parastromateus niger had the highest levels of Ni. The Merluccius bilinearis, Lethrinus nebulosus and Lethrinus nebulosus had the highest levels of $\mathrm{Pb}$. Seriola dumerili, Lethrinus nebulosus, and Lutjanus argentimaculatus had the highest levels of Ti. Therefore, certain species of fish have more potential for bioaccumulation of several trace elements in the ecosystem. It can be assumed from the above that accumulation of the trace elements is more species-related. It was also noted that there was no relationship between the concentration patterns of different trace elements in the different fish species. The results indicated that accumulation of the trace elements (overall mean) analyzed in the sampled fish species was of the following trend: Seriola dumerili > Lethrinus nebulosus $>$ Merluccius bilinearis $>$ Xiphias gladius and the pattern of distribution was $\mathrm{Ni}>\mathrm{Pb}>\mathrm{Ti}>\mathrm{Cd}>$ for all the fish species. Similar findings were reported by Özden., et al. [5].

\section{Arsenic (As)}

The mean of As concentration level was determined at a value of $0.033 \mu / \mathrm{g}$ (Table 2). According to WHO [42], and European Commission [43], the contamination of food with As level is measured as hazardous at concentrations higher than $0.100 \mu / g$, therefore, the present level is not harmful for people consuming fish species available in local markets. In the study of Toppe., et al. [44] who found that the concentration levels of As in nine fish species 
Determination and Comparison of Non-essential and Essential Elements in Different Species of Fish Available in Omani Markets by Using Inductively Coupled Plasma-optical Emission Spectrometry

\begin{tabular}{|c|c|c|}
\hline Non-essential $^{1}$ & Range $(\mu \mathrm{g} / \mathrm{g})$ & Average $\pm S D(\mu \mathrm{g} / \mathrm{g})$ \\
\hline As & $0.012-0.076$ & $0.033 \pm 0.049$ \\
\hline $\mathrm{Cd}$ & $0.000-1.052$ & $0.256 \pm 0.085$ \\
\hline $\mathrm{Ni}$ & $0.000-6.188$ & $1.673 \pm 0.447$ \\
\hline $\mathrm{Pb}$ & $0.000-13.2$ & $1.493 \pm 0.906$ \\
\hline $\mathrm{Ti}$ & $0.061-1.471$ & $0.427 \pm 0.114$ \\
\hline $\mathrm{Cr}$ & 0.059-0.099 & $0.084 \pm 0.003$ \\
\hline $\mathrm{Hg}$ & $0.012-0.049$ & $0.030 \pm 0.004$ \\
\hline
\end{tabular}

Table 2: Non-essential elements in 70 samples (14 species $x$ replicates) of fish with statistical descriptors: range, average, and standard deviation (SD).

${ }^{1}$ As: Arsenic, Cd: Cadmium, Ni: Nickel, Pb: Lead, Ti: Titanium, Cr: Chromium, Hg: Mercury.

ranged from 0.30 to $3.8 \mu / \mathrm{g}$, which are much higher than values in the present study. For the human diet, the FAO/WHO [45] has set the maximum tolerable weekly As intake at $15 \mu / \mathrm{kg}$ body weight. The low levels of As detected in the present study may not release into human organs and may not cause the risk of human pulmonary disease [46]. There was no significant differences in concentration levels of As among the 14 species of fish tested in the current study. While, the variation of the As levels in four fish species (O. niloticus, S. Galilaeus, C. gariepinus and H. nilotics) were greater than those values reported in the present study [47]. The highest As levels determined $0.335 \mu \mathrm{g} / \mathrm{g}$ for Merlangius merlangus, $0.400 \mu \mathrm{g} / \mathrm{g}$ for Solea solea, and $0.966 \mu \mathrm{g} / \mathrm{g}$ for Mullus surmuletus [5].

Cadmium (Cd)

\begin{tabular}{|c|c|c|c|c|c|c|c|}
\hline \multirow[t]{2}{*}{ Fish species } & \multicolumn{7}{|c|}{ Non-essential elements ${ }^{1}$} \\
\hline & As & Cd & $\mathbf{N i}$ & $\mathbf{P b}$ & $\mathbf{T i}$ & $\mathrm{Cr}$ & $\mathbf{H g}$ \\
\hline \multicolumn{8}{|l|}{ Fish Species $^{2}$} \\
\hline EWFF & $0.050 \pm 0.001$ & $0.186 \pm 0.033^{\mathrm{b}}$ & $0.123 \pm 0.032^{\mathrm{b}}$ & $0.680 \pm 0.053^{\mathrm{b}}$ & $0.186 \pm 0.024^{a}$ & $0.088 \pm 0.004$ & $0.049 \pm 0.002$ \\
\hline NF & $0.036 \pm 0.002$ & $0.125 \pm 0.022^{\mathrm{b}}$ & $0.498 \pm 0.041^{\mathrm{b}}$ & $0.374 \pm 0.035^{\mathrm{b}}$ & $0.062 \pm 0.002^{\mathrm{a}}$ & $0.089 \pm 0.003$ & $0.013 \pm 0.001$ \\
\hline SB & $0.024 \pm 0.004$ & $0.187 \pm 0.034^{\mathrm{b}}$ & $0.249 \pm 0.024^{\mathrm{b}}$ & $0.623 \pm 0.054^{\mathrm{b}}$ & $0.685 \pm 0.045^{\mathrm{a}}$ & $0.088 \pm 0.006$ & $0.022 \pm 0.002$ \\
\hline AWFF & $0.053 \pm 0.003$ & $0.245 \pm 0.043^{b}$ & $0.368 \pm 0.023^{b}$ & $13.23 \pm 1.234^{\mathrm{d}}$ & $0.674 \pm 0.055^{\mathrm{a}}$ & $0.095 \pm 0.007$ & $0.048 \pm 0.003$ \\
\hline GF & $0.018 \pm 0.004$ & $0.061 \pm 0.003^{\mathrm{b}}$ & $0.306 \pm 0.025^{b}$ & $0.000 \pm 0.000^{\mathrm{a}}$ & $0.061 \pm 0.001^{\mathrm{a}}$ & $0.059 \pm 0.004$ & $0.033 \pm 0.001$ \\
\hline PWFF & $0.048 \pm 0.003$ & $0.245 \pm 0.033^{\mathrm{b}}$ & $0.123 \pm 0.016^{\mathrm{b}}$ & $0.675 \pm 0.076^{\mathrm{b}}$ & $0.061 \pm 0.001^{\mathrm{a}}$ & $0.099 \pm 0.006$ & $0.052 \pm 0.002$ \\
\hline $\mathrm{TF}$ & $0.037 \pm 0.005$ & $0.000 \pm 0.000^{\mathrm{a}}$ & $0.248 \pm 0.036^{\mathrm{b}}$ & $0.931 \pm 0.096$ & $0.124 \pm 0.02^{\mathrm{a}}$ & $0.098 \pm 0.007$ & $0.043 \pm 0.001$ \\
\hline SF & $0.028 \pm 0.004$ & $0.920 \pm 0.081^{\mathrm{c}}$ & $0.123 \pm 0.023^{b}$ & $0.184 \pm 0.021^{b}$ & $0.491 \pm 0.039^{\mathrm{a}}$ & $0.066 \pm 0.004$ & $0.014 \pm 0.001$ \\
\hline RSF & $0.012 \pm 0.003$ & $0.000 \pm 0.000^{\mathrm{a}}$ & $6.188 \pm 0.092^{c}$ & $0.743 \pm 0.054^{\mathrm{b}}$ & $0.743 \pm 0.071^{\mathrm{a}}$ & $0.079 \pm 0.007$ & $0.023 \pm 0.002$ \\
\hline $\mathrm{BPF}$ & $0.076 \pm 0.004$ & $0.123 \pm 0.024^{\mathrm{a}}$ & $2.771 \pm 0.073^{c}$ & $0.431 \pm 0.032^{\mathrm{b}}$ & $0.185 \pm 0.022^{a}$ & $0.086 \pm 0.006$ & $0.012 \pm 0.001$ \\
\hline LEF & $0.019 \pm 0.001$ & $0.131 \pm 0.011^{\mathrm{a}}$ & $0.248 \pm 0.025^{b}$ & $1.055 \pm 0.092^{c}$ & $0.434 \pm 0.024^{a}$ & $0.067 \pm 0.004$ & $0.014 \pm 0.001$ \\
\hline $\mathrm{EF}$ & $0.017 \pm 0.005$ & $0.123 \pm 0.023^{\mathrm{a}}$ & $0.551 \pm 0.043^{b}$ & $0.919 \pm 0.087^{c}$ & $1.471 \pm 0.095^{b}$ & $0.075 \pm 0.006$ & $0.024 \pm 0.002$ \\
\hline $\mathrm{AF}$ & $0.022 \pm 0.002$ & $1.052 \pm 0.092^{\mathrm{c}}$ & $0.557 \pm 0.044^{\mathrm{b}}$ & $0.681 \pm 0.065^{b}$ & $1.114 \pm 0.085^{b}$ & $0.086 \pm 0.007$ & $0.023 \pm 0.001$ \\
\hline MF & $0.019 \pm 0.004$ & $0.185 \pm 0.014^{\mathrm{b}}$ & $0.000 \pm 0.000^{\mathrm{a}}$ & $0.370 \pm 0.031^{\mathrm{b}}$ & $0.370 \pm 0.032^{\mathrm{a}}$ & $0.094 \pm 0.0083$ & $0.034 \pm 0.002$ \\
\hline Significant & NS & $*$ & $*$ & $*$ & $*$ & NS & NS \\
\hline
\end{tabular}

Table 3: Mean $(\mu \mathrm{g} / \mathrm{g})$ and standard error of mean of non-essential elements in 14 fish samples selected from local markets.

${ }^{1}$ As: Arsenic, Cd: Cadmium, Ni: Nickel, Pb: Lead, Ti: Titanium, Cr: Chromium, Hg: Mercury.

${ }^{2}$ Fish species: EWFF: Eastco White Fish Fillet, NF: Naiser Fish, SB: Sea Bream (Red Koffer), AWFF, Aquamarine White Fish Fillet, GF: Grouper Fish (Hammour), PWFF: Premium White Fish Fillet, TF: Tuna Fish, SF: Sword Fish, RSF: Red snapper Fish, BPF: Black Pomfret

Fish, LEF: Local Emperor Fish, EF: Emperor Fish, AF: Amberjack Fish, MF: Mackerel Fish.

$\mathrm{Cd}$ is considered one of the most harmful trace elements for human health. The overall concentration of Cd was ranged from 0.00 to $1.05 \mu / \mathrm{g}$ in all fish species samples analyzed with overall mean value of $0.256 \mu \mathrm{g} / \mathrm{g}$. Considering the maximum allowed limit for $\mathrm{Cd}$ is $0.5 \mu / \mathrm{g}$ for fish [43], the concentration levels of $\mathrm{Cd}$ found in Xiplias gladius and Seriola dumerili were 0.920 and $1.052 \mu \mathrm{g} / \mathrm{g}$ respectively which are particularly toxic for humans. Consump- tion of high quantities of Xiplias gladius and Seriola dumerili species may lead to acute renal failure in humans due to sever chronic Cd poisoning [48]. The mean Cd concentration levels in 10 fresh and frozen species of commercially important fish in Oman was in the range of 0.01 to $1.0 \mu \mathrm{g} / \mathrm{g}$ [49] and concluded that the results showed small variations in Cd levels between fish species tested. Similar differences between fish species were found by Mansour 
and Sidky [50], who reported a range from 0.00 to $0.79 \mu \mathrm{g} / \mathrm{g}$ between Mugil Sp. And Solea aegyptiaca and concluded that the Mugil $s p$ spcies had larger variations $(0.019-0.790 \mu \mathrm{g} / \mathrm{g})$ than samples from the Solea aegyptiaca species $(0.00-0.001 \mu \mathrm{g} / \mathrm{g})$. Higher level of $\mathrm{Cd}(7.72-11.58 \mu / \mathrm{g})$ than the present results were reported by Hamilton., et al. [51] in different fish species. The accumulation of $\mathrm{Cd}$ in the human body may cause prostate cancer and breast cancer in humans [52]. In the present study, edible portions from the 12 fish species contained Cd levels below of $0.5 \mu \mathrm{g} / \mathrm{g}$ and does not cause particular food safety concerns, with the exception of some allergic reactions. Mean Cd concentration levels found in this study were lower than those reported by Ahmed., et al. [53] and Akoto., et al. [54] who reported Cd mean concentrations of $0.96 \pm 0.15$ and $0.275 \pm 0.47 \mu \mathrm{g} / \mathrm{g}$, respectively in fish tissues. Fawole., et al. [47] found the concentration level of $\mathrm{Cd}$ in four species of fish ranged from 100 to $200 \mu \mathrm{g} / \mathrm{g}$. Keskin., et al. [55] reported Cd concentrations of $0.054 \mu \mathrm{g} / \mathrm{g}$ in Merlangius merlangus; $0.012 \mu \mathrm{g} / \mathrm{g}$ in Mullus barbatus; and $0.022 \mu \mathrm{g} / \mathrm{g}$ in Solea solea.

\section{Nickle (Ni)}

The range of concertation levels of $\mathrm{Ni}$ in 14 fish species were found from 0.000 to $6.188 \mu \mathrm{g} / \mathrm{g}$ with an overall mean of $1.673 \mu \mathrm{g} / \mathrm{g}$ (Table 3). The maximum allowed limits [56] for $\mathrm{Ni}$ in fish is 70-80 $\mu \mathrm{g} / \mathrm{g}$. The concentration levels of $\mathrm{Ni}$ in all the fish samples were below the maximum limit, which will not cause health hazards but it may cause some allergic reaction [57]. Similar concentrations of Ni (5.95-14.45 $\mu / g)$ were reported by Hamilton., et al. [51]. If the concentrations of $\mathrm{Ni}$ are above the set limit it may cause cancer of nasal cavity and the lungs [58]. The concentration values of $\mathrm{Ni}$ in this study were higher than those reported by Idodo-Umeh [59] who recorded $1.64-3.58 \mu \mathrm{g} / \mathrm{g}$ from fish from the Olomoro water. Higher contaminated fish with $\mathrm{Ni}$ than the present study was reported by De Vive., et al. [60] who found high levels of $\mathrm{Ni}$ in fish and attributed the contamination to suspend particles and plants in water with high percentage of Ni. In the present study, the tissue samples of 2 of 14 fish species contained levels of Ni in excess of $2 \mu \mathrm{g} / \mathrm{g}$ (Table 3). For example, the levels of $\mathrm{Ni}$ in L.campechannus and parastromateus niger samples showed a significant $(\mathrm{P}<0.05)$ elevated Ni concentration ( $6.188 \mu \mathrm{g} / \mathrm{g})$ and $2.771 \mu \mathrm{g} / \mathrm{g}$, respectively than other fish samples. The present results are in agreement with Murtala., et al. [61], who found that the concentration of $\mathrm{Ni}$ varied between $H$. forskahlii, H. bebe occidentalis and C. gariepinus. The H. littorale exhibited mean levels of $13.5 \mu \mathrm{g} / \mathrm{g}$ Ni element [62] that is higher than the mean value in the present study. Furthermore, Mansour and Sidky [50] found that samples from Mugil sp contained higher level of $\mathrm{Ni}(0.012-4.540 \mu \mathrm{g} / \mathrm{g})$ than those from Solea aegyptiaca (0.00-0.00 $\mu \mathrm{g} / \mathrm{g}$ ). However, lower level (0.24 and $0.36 \mu \mathrm{g} / \mathrm{g}$ in Mormyops deliciosus and Mormyrus macrophthalmus has been reported by Oronsaye., et al. [63] from the Ikpoba river dam. The edible portion of 4 of 14 fish species were contaminated with $\mathrm{Ni}$ above the maximum recommended limits of $0.5-0.6 \mu \mathrm{g} / \mathrm{g}$ (FEPA, 2003) in fish.

\section{Lead $(\mathrm{Pb})$}

The average concentration value of $\mathrm{Pb}$ in all fish samples was $1.493 \mu / \mathrm{g}(0.00-13.2)$ as given in Table 3. With the exception of two species Epinephalus chlorostigma and Xiphias gladius, the remaining 12 fish species were above the maximum allowed limits of $\mathrm{Pb}$ $(0.3 \mu \mathrm{g} / \mathrm{g})$ in fish muscle [43]. Other findings have also reported similar values of $\mathrm{Pb}$ in fish tissues. Staniskiene., et al. [64] and Akoto., et al., [54] reported $\mathrm{Pb}$ concentrations of 6.82 and $3.13 \mu \mathrm{g} / \mathrm{g}$ in fish, respectively. Lower levels, of $\mathrm{Pb}(1.70-6.16 \mu / \mathrm{g})$ to those in the present study were reported by Hamilton., et al. [51]. The present findings were higher compared to the findings $0.395-0.62 \mu \mathrm{g} / \mathrm{g}$ of Doherty., et al. [65], while lower than $9 \mu \mathrm{g} / \mathrm{g}$ [66], $9.69 \mu \mathrm{g} / \mathrm{g}$ [53], 6,82 $\mu \mathrm{g} / \mathrm{g}$ [54] and 0.02-0.744 $\mathrm{\mu g} / \mathrm{g}$ [49] of Pb in different species of fish. Daka., et al. [67] also obtained 0.01-0.06 $\mu \mathrm{g} / \mathrm{g}$ in fish species from Nigeria. Liver damage and renal failure in humans may be due to extreme accumulation of heavy metals [68,69]. Therefore, The FAO, WHO, EU and other regulatory bodies of various countries have established the maximum permitted concentrations of heavy metals in foodstuffs $[70,71]$. This study indicated that tissue from Epinephalus chlorostigma and Xiphias gladius species had significantly $(\mathrm{P}<0.05)$ less levels of $\mathrm{Pb}$ than the other species of fish. A similar conclusion was reported by Murtala., et al. [61], who found significant differences in concentration levels of $\mathrm{Pb}$ between $H$. forskahlii,_H. bebe occidentalis, and C. gariepinus fish species. Farombi., et al. [72] also reported 0.73 to $4.12 \mu \mathrm{g} / \mathrm{g}$ difference in Pb levels in C. gariepinus, Obasohan., et al. [28] also reported $0.10-0.83 \mu \mathrm{g} / \mathrm{g}$ in fish species and Oronsaye., et al. [63] also gave $3.53 \mu \mathrm{g} / \mathrm{g}$ and $2.67 \mu \mathrm{g} / \mathrm{g}$ in Mormyrops delicisus and Mormyrus macrophthalmus. Moreover, Oronsaye., et al. [63] found that contamination levels ranged from $3.53 \mu \mathrm{g} / \mathrm{g}$ to $2.67 \mu \mathrm{g} / \mathrm{g}$ in Mormyrops delicisus and Mormyrus macrophthalmus. Doherty., et al. [65] reported $0.44 \mathrm{\mu g} / \mathrm{g}$ and $0.62 \mu \mathrm{g} / \mathrm{g}$ of lead in C. nigrodigitatus and T. guineensis respectively. Keskin., et al. [55] reported Pb concentrations of $0.207 \mu \mathrm{g} / \mathrm{g}$ in Merlangius merlangus, $0.035 \mu \mathrm{g} / \mathrm{g}$ in Mullus barbatus, and 0.133 $\mu \mathrm{g} / \mathrm{g}$ in Solea solea. The Mugil sp species had lower concentrations $(0.030-12.00 \mu \mathrm{g} / \mathrm{g})$ of $\mathrm{Pb}$ compared to the Solea aegyptiaca samples $(0.144-24.3 \mu \mathrm{g} / \mathrm{g})[50]$.

\section{Titanium (Ti)}

The range concentration levels of Ti in 14 fish species samples was found to be between 0.061 and $1.471 \mu \mathrm{g} / \mathrm{g}$ with a mean value of $0.427 \mu \mathrm{g} / \mathrm{g}$. The maximum acceptable weekly intake for Ti is 14 $\mathrm{mg} / \mathrm{kg}$ body weight [73]. This study showed substantial differences between the mean values of fish species. Muscle samples from 
Determination and Comparison of Non-essential and Essential Elements in Different Species of Fish Available in Omani Markets by Using Inductively Coupled Plasma-optical Emission Spectrometry

Lethrinus nebulosus $(1.471 \mu \mathrm{g} / \mathrm{g})$ and Seriola dumerili $(1,114 \mu \mathrm{g} / \mathrm{g})$ species had significantly $(\mathrm{P}<0.05)$ higher Ti concentration levels than those from other species.

Chromium (Cr)

In the present study, the contamination level of $\mathrm{Cr}$ in all fish samples was $0.030 \mu \mathrm{g} / \mathrm{g}$ with a range from 0.012 to $0.063 \mu \mathrm{g} / \mathrm{g}$ as given in Table 3. The maximum allowed limit, $12-13 \mu \mathrm{g} / \mathrm{g}$ [43]. Similar to this study, the Cr levels in three species of fish (Merluccius merluccius, Mugil sp., and Mullus surmuletus) ranged from 0.010 to $0.079 \mu \mathrm{g} / \mathrm{g}$ [74]. However, Uluozlu., et al. [75] found Cr concentrations of Mullus surmuletus at $1.63 \mu \mathrm{g} / \mathrm{g}$, while Meche., et al. [62] found that tissue samples from Hypostomus punctatus and Serrasalmus spilopleura fish species contained more than $1 \mu \mathrm{g} / \mathrm{g}$ Cr. High concentrations of $\mathrm{Cr}$ in fish reported by Jordao., et al. [76, 77]. The concentration of $\mathrm{Cr}$ in the tissue of eight of seventeen of fish species was found to be in excess of $1 \mu \mathrm{g} / \mathrm{g}$ [62]. Variations in concentration levels of $\mathrm{Cr}$ in three different fish species (H. forskahlii, H. bebe occidentalis and C. gariepinus) were also reported by Murtala., et al. [61]. Concentrations of $\mathrm{Cr}$ level of $0.40-5.61 \mu \mathrm{g} / \mathrm{g}$ in Parachanna obscura was reported by Obasohan [29] and $29.8-31.6 \mu \mathrm{g} / \mathrm{g}$ from T. zillii and $28.1-32.2 \mu \mathrm{g} / \mathrm{g}$ from C. gariepinus reported by Ishaq., et al. [78]. Moreover, Nwani., et al., [79] found $1.19 \mu \mathrm{g} / \mathrm{g} \mathrm{Cr}$ in Chyrsichthys nigrodigitatus from freshwater while Odoemelan [80] found $1.86 \mu \mathrm{g} / \mathrm{g}$ in A. nurse. In the study of Mansour and Sidky [50], the Mugil sp species had higher concentrations (1.19-3.05 $\mu \mathrm{g} / \mathrm{g})$ of $\mathrm{Cr}$ compared to the Solea aegyptiaca samples (0.048-1.86 $\mu \mathrm{g} / \mathrm{g})$.

The results in the present study were lower than most of the previous studies. The levels of $\mathrm{Cr}$ presented in 14 fish species in the present study were less than most of published results and lower than maximum recommended limits of $0.15-1.0 \mu \mathrm{g} / \mathrm{g}$ [81] in fish.

\section{Mercury (Hg)}

The mean concentration value of $\mathrm{Hg}$ was detected in all fish samples with an average value of $0.033 \mu \mathrm{g} / \mathrm{g}(0.012-0.049 \mu \mathrm{g} / \mathrm{g})$ as given in Table 3, which may not be significant because the maximum allowed limit for $\mathrm{Hg}$ is $0.05 \mu / \mathrm{g}$ for fish [43]. Therefore, $\mathrm{Hg}$ level in 14 fish species available in the local markets is not particularly toxic for humans at this level and does not cause particular food safety concern [57,82]. Higher level of Hg 11.41-17.03 $\mu / g$ [50], 0.2929-1.038 $\mu / g$ [5], and $0.01-570 \mu \mathrm{g} / \mathrm{g}[49]$, these range values are higher than the present results. Similar values were reported by Keskin., et al. [55] who found $\mathrm{Hg}$ concentrations of $0.0352 \mu / \mathrm{g}$ in Merlangius merlangus, 0.434 $\mu / g$ in Mullus barbatus, and $0.329 \mu / g$ in Solea solea.

\section{Essential elements}

The overall concentrations of seven essential elements in the edible part of 14 species of fish are presented in Table 4. P, Ca, and Mg were mostly plentiful in the fish tissue analyzed in that order. For example, the Ocyurus chrysurus, Pagellus affinis, Epinephelus coides and Seriola dumerili had among the highest levels of certain elements tested. $\mathrm{Se}, \mathrm{Cu}$ and $\mathrm{Zn}$ elements were detected in all fish samples at small to moderate levels. Ten of the 14 species are demersal fish that feed on detritus, while the other four species are pelagic fish, and thus the high levels of metals in these species cannot be explained by feeding behaviors. This study presented differences in the concentration levels of 14 elements between selected species of fish. This result was supported by the findings of Mansour and Sidky [50] and Ako and Salihu [84] who found variations in contamination levels of elements between species of fish and concluded that the differences may be due to chemical forms of trace elements and their levels in the water. Considering the remaining seven essential elements analyzed, there was no well-defined order of scale within and across the fish tissue samples analyzed. The variations in the concentration of essential elements in fish tissues studied could have been as a result of the rate in which they are available in the water and the ability of the fish to absorb these inorganic elements from their diets [85].

Copper (Cu)

\begin{tabular}{|c|c|c|}
\hline Essential-elements $^{\mathbf{1}}$ & Range $(\boldsymbol{\mu g} / \mathbf{g})$ & Average $\mathbf{\pm S D}(\boldsymbol{\mu} / \mathbf{g})$ \\
\hline $\mathrm{Cu}$ & $0.434-6.314$ & $2.487 \pm 0.333$ \\
\hline $\mathrm{Fe}$ & $32.81-99.91$ & $68.44 \pm 19.12$ \\
\hline $\mathrm{Zn}$ & $4.512-6.421$ & $5.102 \pm 0.727$ \\
\hline $\mathrm{P}$ & $1999-2542$ & $2210.3 \pm 0155$ \\
\hline $\mathrm{Ca}$ & $299.9-345.6$ & $326.1 \pm 4.924$ \\
\hline $\mathrm{Se}$ & $0.212-0.312$ & $0.246 \pm 0.008$ \\
\hline $\mathrm{Mg}$ & $137.5-150.4$ & $143.6 \pm 1.526$ \\
\hline
\end{tabular}

Table 4: Essential elements in 70 samples of fish with statistical descriptors: range, average, and standard deviation (SD). ${ }^{1} \mathrm{CU}$ : Copper, F: Iron, Zn: Zinc, P: Phosphorus, Ca: Calcium, Se: Selenium, Mag: Magnesium.

The $\mathrm{Cu}$ concentrations as shown in Table 4 in the fish muscle is in the range $0.434-6.314 \mu \mathrm{g} / \mathrm{g}$ with an average value of $2.487 \mu \mathrm{g} / \mathrm{g}$. The maximum allowed limits for $\mathrm{Cu}$ in fish was $30.0 \mu \mathrm{g} / \mathrm{g}$ for human health risk concerns [86]. The overall concentration level of $\mathrm{Cu}$ in 14 fish samples was below this value. Similar values for $\mathrm{Cu}$ in fish tissue was reported by Ozden., et al. [5]. In the present study, tissue samples from Seriola du- 
Determination and Comparison of Non-essential and Essential Elements in Different Species of Fish Available in Omani Markets by Using Inductively Coupled Plasma-optical Emission Spectrometry

merili contained significantly $(\mathrm{P}<0.05)$ higher levels of $\mathrm{Cu}(6.314 \mu \mathrm{g} / \mathrm{g})$ than those from other species, while samples from Parastromateus niger contained significantly lower $(\mathrm{P}<0.05)$ lower concentrations of $\mathrm{Cu}$ $(0.434 \mu \mathrm{g} / \mathrm{g})$ compared to other fish species tissue (Table 5). Similar values were reported by Ozden., et al. [5] in Solea solea, Mullus barbatus, and Merlangius merlangus throughout the year. Mansour and Silky [50] also reported similar values to the present study for two fish spe-

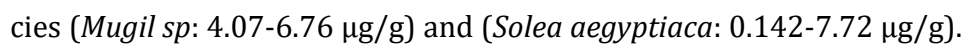
Lower levels of $\mathrm{Cu}$ in fish species than the present values were reported by Çelik and Oehlenschläger [87] who found mean $\mathrm{Cu}$ concentrations in three different species of $0.29,0.22$, and $0.12 \mu \mathrm{g} / \mathrm{g}$. While Keskin., et al. [55] reported Cu concentrations of 9.487, 0.300, 0.370 $\mu \mathrm{g} / \mathrm{g}$ in Merlangius merlangus, Mullus barbatus and Solea solea. Although, $\mathrm{Cu}$ is considered an essential part of enzymes and is required for the synthesis of hemoglobin, it can cause harm at high concentrations [88]. The Recommended Dietary Allowances (RDA) for copper in normal healthy adults is $0.9 \mathrm{mg} /$ day.

Iron $(\mathrm{Fe})$

Fe concentration levels in 14 species of fish tissue varied considerably with a range from 32.82 to $99.91 \mu \mathrm{g} / \mathrm{g}$ with a mean value of 68.44 $\mu \mathrm{g} / \mathrm{g}$ (Table 4). Ocyurus chrysurus, Pagellus affinis, and Epinephelus coi- des species contained significantly $(\mathrm{P}<0.05)$ higher concentrations of Fe than those from other species (Table 5). Similarly, Bogard., et al. [89] found a great variation in Fe concentration levels among 30 fish species. The present findings showed a wide range in Fe concentration levels compared to values reported in the global FAO/INFOODS database on fish [90]. On the other hand, tissue samples from Merluccius bilinearis, and R. kanagurta species contained the lowest Fe levels than those from other species (Table 5). In the study of Suseno., et al. [82], the Fe concentration levels ranged from $0.4 \mu \mathrm{g} / \mathrm{g}$ in Antigonia rubescens to $0.8 \mu \mathrm{g} / \mathrm{g}$ in Xenolepidichthys dalgleishi. Similar Fe levels were reported as $163 \mu \mathrm{g} / \mathrm{g}$ for mullus surmuletus, $82.7 \mu \mathrm{g} / \mathrm{g}$ for Mugil cephalus, $104 \mu \mathrm{g} / \mathrm{g}$ for Mullus surmuletus [75], 5.40-8 $\mu \mathrm{g} / \mathrm{g}$ for Mugil cephalus [91], and $70.28 \mu \mathrm{g} / \mathrm{g}$ for Mugil cephalus [92]. Mansour and Silky [50] found higher concentrations of Fe than the present study for Mugil sp (37.0-372 $\mu \mathrm{g} / \mathrm{g}$ ) and Solea aegyptiaca (2.07-186 $\mu \mathrm{g} / \mathrm{g})$. Fe is an essential element for life due to its presence in living cells and is necessary for the hemoglobin, myoglobin, and certain enzymes. Overall, the concentration levels of Fe in different species of fish available in local markets indicates that several species may contribute significantly to dietary Fe intake among local people. The Food and Drug Administration recommended daily allowance is $18 \mathrm{mg}$ for iron [56].

Zinc (ZN)

\begin{tabular}{|c|c|c|c|c|c|c|c|}
\hline \multicolumn{7}{|c|}{ Essential elements $^{\mathbf{1}}$} \\
\hline Fish species $^{2}$ & Cu & Fe & Zn & P & Ca & Se & Mg \\
\hline EWFF & $2.041 \pm 0.454^{\mathrm{b}}$ & $32.81 \pm 2.17^{\mathrm{a}}$ & $5.330 \pm 0.776$ & $2088 \pm 5.66$ & $328.3 \pm 2.11$ & $0.212 \pm 0.041$ & $139.8 \pm 1.062$ \\
\hline NF & $2.242 \pm 0.563^{\mathrm{b}}$ & $99.91 \pm 6.77^{\mathrm{c}}$ & $4.984 \pm 0.645$ & $2064 \pm 4.79$ & $325.1 \pm 1.56$ & $0.312 \pm 0.031$ & $140.8 \pm 1.112$ \\
\hline SB & $1.991 \pm 0.231^{\mathrm{b}}$ & $90.63 \pm 7.11^{\mathrm{c}}$ & $4.897 \pm 0.599$ & $2542 \pm 6.04$ & $313.2 \pm 2.06$ & $0.221 \pm 0.032$ & $143.9 \pm 1.213$ \\
\hline AWFF & $2.391 \pm 0.223^{\mathrm{b}}$ & $61.72 \pm 4.76^{\mathrm{ab}}$ & $5.712 \pm 0.666$ & $2079 \pm 3.77$ & $334.7 \pm 2.09$ & $0.243 \pm 0.043$ & $137.5 \pm 1.001$ \\
\hline GF & $2.382 \pm 0.342^{\mathrm{b}}$ & $98.83 \pm 6.89^{\mathrm{c}}$ & $5.112 \pm 0.531$ & $1999 \pm 3.65$ & $345.6 \pm 3.08$ & $0.224 \pm 0.035$ & $139.6 \pm 0.958$ \\
\hline PWFF & $1.903 \pm 0.214^{\mathrm{b}}$ & $72.24 \pm 5.43^{\mathrm{b}}$ & $6.421 \pm 0.554$ & $2263 \pm 4.22$ & $343.6 \pm 2.89$ & $0.235 \pm 0.041$ & $150.1 \pm 1.223$ \\
\hline TF & $2.674 \pm 0.178^{\mathrm{b}}$ & $73.82 \pm 4.77^{\mathrm{b}}$ & $6.254 \pm 0.598$ & $2380 \pm 5.34$ & $301.7 \pm 1.78$ & $0.253 \pm 0.031$ & $150.4 \pm 1.312$ \\
\hline SF & $2.393 \pm 0.243^{\mathrm{b}}$ & $56.93 \pm 4.71^{\mathrm{ab}}$ & $4.134 \pm 0.357$ & $2285 \pm 4.88$ & $371.1 \pm 3.01$ & $0.312 \pm 0.043$ & $142.9 \pm 1.154$ \\
\hline RSF & $2.592 \pm 0.311^{\mathrm{b}}$ & $71.64 \pm 5.87^{\mathrm{b}}$ & $3.798 \pm 0.297$ & $2008 \pm 2.99$ & $299.9 \pm 1.65$ & $0.233 \pm 0.031$ & $143.4 \pm 1.231$ \\
\hline BPF & $0.434 \pm 0.042^{\mathrm{a}}$ & $65.82 \pm 4.99^{\mathrm{ab}}$ & $4.512 \pm 0.421$ & $2153 \pm 3.31$ & $321.7 \pm 2.43$ & $0.245 \pm 0.044$ & $140.9 \pm 1.011$ \\
\hline LEF & $2.233 \pm 0.265^{\mathrm{b}}$ & $58.92 \pm 4.31^{\mathrm{ab}}$ & $5.412 \pm 0.545$ & $2222 \pm 3.76$ & $322.8 \pm 2.33$ & $0.244 \pm 0.054$ & $139.9 \pm 0.875$ \\
\hline EF & $3.004 \pm 0.311^{\mathrm{b}}$ & $57.73 \pm 3.98^{\mathrm{ab}}$ & $4.652 \pm 0.443$ & $2354 \pm 4.58$ & $316.8 \pm 1.32$ & $0.222 \pm 0.033$ & $142.6 \pm 0.989$ \\
\hline AF & $6.314 \pm 0.897^{\mathrm{c}}$ & $73.64 \pm 5.73^{\mathrm{b}}$ & $4.985 \pm 0.525$ & $2265 \pm 3.33$ & $319.8 \pm 1.33$ & $0.232 \pm 0.032$ & $143.9 \pm 1.322$ \\
\hline MF & $2.223 \pm 0.210^{\mathrm{b}}$ & $43.81 \pm 3.45^{\mathrm{a}}$ & $5.231 \pm 0.461$ & $2234 \pm 3.17$ & $321.8 \pm 2.15$ & $0.254 \pm 0.029$ & $144.8 \pm 1.411$ \\
\hline Significant & $*$ & $*$ & NS & NS & NS & NS & NS \\
\hline
\end{tabular}

Table 5: Mean $(\mu \mathrm{m} / \mathrm{g})$ and standard error of mean of essential elements in 14 fish samples selected from the local markets.

${ }^{1}$ CU: Copper, F: Iron, Zn: Zinc, P: Phosphorus, Ca: Calcium, Se: Selenium, Mag: Magnesium.

${ }^{2}$ Fish species: EWFF: Eastco White Fish Fillet, NF: Naiser Fish, SB: Sea Bream (Red Koffer), AWFF, Aquamarine White Fish Fillet, GF: Grouper Fish (Hammour), PWFF: Premium White Fish Fillet, TF: Tuna Fish, SF: Sword Fish, RSF: Red snapper Fish, BPF: Black Pomfret Fish, LEF: Local Emperor Fish, EF: Emperor Fish, AF: Amberjack Fish, MF: Mackerel Fish. 
The $\mathrm{Zn}$ concentration levels in 14 species of fish ranged from 4.512 to $6.421 \mu \mathrm{g} / \mathrm{g}$ with an overall mean level of $5.102 \mu \mathrm{g} / \mathrm{g}$ (Table 5). The variation between the fish species was small and non-significant. Similar results in different fish species were reported by Meche., et al. [62]. The amount ranging from $3.9 \mu \mathrm{g} / \mathrm{g}$ in Rouleina guentheri to $6.8 \mu \mathrm{g} / \mathrm{g}$ in Alepocephalus bicolor [82]. Higher values of $\mathrm{Zn}$ in fish species than the present study were reported by Mansour and Sidky [50] who found that the range of $\mathrm{Zn}$ in Mugil sp from $12.0-23.83 \mu \mathrm{g} / \mathrm{g}$ and from 2.37 to $48.7 \mu \mathrm{g} / \mathrm{g}$ in Solea aegyptiaca. Zn has important physiological immune functions, protein synthesis [93], wound healing [94], and DNA synthesis [95]. However, due to its high bioavailability [86], excessive $\mathrm{Zn}$ intake can cause a range of physiological problems [96]. Zn levels of Merlangius merlangus ranged from 3.0 to $0.31 \mu \mathrm{g} / \mathrm{g}$ [97] and the Zn levels of Mullus barbatus, Merlangius merlangus, and Solea solea were 5.03, 3.84, and $3.72 \mu \mathrm{g} / \mathrm{g}$ [87]. In the present study, the concentration levels of $\mathrm{Zn}$ in all fish samples was below the maximum allowed limit of $30 \mu \mathrm{g} / \mathrm{g}$ of Zn for safe human consumption [98]. Therefore, the amounts of $\mathrm{Zn}$ in the fish species available in local markets cannot cause health problems to consumers. $\mathrm{Zn}$ is an essential-element for humans and its toxicity is rare but, at concentrations of up to 40 $\mu \mathrm{g} / \mathrm{g}, \mathrm{Zn}$ may induce toxicity, characterized by symptoms of nausea, loss of appetite, irritability, pain and muscular stiffness [48]. The FDA (54) recommended daily allowance of $15 \mathrm{mg}$ for zinc.

Phosphorous (P)

This study showed that the concentration of $\mathrm{P}$ ranged from 1999 to $2542 \mu \mathrm{g} / \mathrm{g}$ with a mean of $2210.3 \mu \mathrm{g} / \mathrm{g}$ (Table 5). Similar values were reported by FAO/INFOODS [90]. The present results indicate no significant differences in $\mathrm{P}$ concentration levels between the fish species. Edible portion of Pagellus affinis species had the highest while Epinephalus chlorostigma had the lowest content (Table 5). The P levels were between 1960 and $260 \mu \mathrm{g} / \mathrm{g}$ in Polymixia sp and 2300 and $820 \mu \mathrm{g} / \mathrm{g}$ in Rouleina guenther [82].

\section{Calcium (Ca)}

Ca level ranged from 299.9 to $345.6 \mu \mathrm{g} / \mathrm{g}$ (Table 5) with a mean content of $326.1 \mu \mathrm{g} / \mathrm{g}$ and similar values were reported by others [90]. The present values reveal that most of the fish species assessed would meet $\geq 30 \%$ of the recommended Ca intakes. Ca is an essential element for humans, and represents around $2 \%$ of body weight in the human body and is the main structure of bones and teeth. Adequate Ca intake during childhood may be linked to boosted bone mass, breast cancer, bone fragility, and hip fractures, and a reduction of osteoporosis [16]. The small variations in the values of Ca between the fish species might be due to an increase in the proportion of bone to flesh as the fish grow $[47,99]$. The Ca level ranged from $274.8 \mu \mathrm{g} / \mathrm{g}$ in Setarches guentheri to $400.2 \mu \mathrm{g} / \mathrm{g}$ $\mathrm{g}$ in Rouleina guentheri [82]. In two fish species (H. niloticus and $C$. gariepinus), Fawole., et al. [47] reported high concentration of $\mathrm{Ca}$ due to the benthic nature of these species and their relative preference for consumption of hard structure. Similarly [99], stated that the high Ca content found in H. niloticus and C. angullaris may probably be due to preferential accumulation and calcification of scales and hard tissues. The current study indicates that variety of fish species are a significant source of high bioavailable dietary Ca for Omani.

\section{Selenium (Se)}

The range of Se levels in all fish species ranged from 0.212 to $0.312 \mu \mathrm{g} / \mathrm{g}$ with overall mean of $0.246 \mu \mathrm{g} / \mathrm{g}$ (Table 5). The Se concentrations in species of fish analyzed in the present study showed small non-significant differences between them. The concentration levels of Se in the present study are consistent with values reported by FAO/INFOODS [90]. The findings of the present study showed that tissue samples from Ocyurus chrysurus contained the highest concentration of Se $(0.312 \mu \mathrm{g} / \mathrm{g})$ while Merluccius bilinearis contained the lowest Se level $(0.12 \mu \mathrm{g} / \mathrm{g})$ of other species. Similar values were reported by Suseno., et al. [82] who found Se levels between $0.2 \mu \mathrm{g} / \mathrm{g}$ in Alepocephalus bicolor and $0.4 \mu \mathrm{g} / \mathrm{g}$ in Synagrops japonicas. Se content of Solea solea ranged between 0.307 and $0.641 \mu \mathrm{g} / \mathrm{g}$ ), while Se levels in Merlangius merlangus ranged from 0.331 to $0.478 \mu \mathrm{g} / \mathrm{g}$.

Magnesium (Mg)

The range of Mg level in 14 species of fish ranged from 137.5 to $150.4 \mu \mathrm{g} / \mathrm{g}$ with overall mean of $143.6 \mu \mathrm{g} / \mathrm{g}$ (Table 5). In the present study, Mg concentrations in species of fish tested showed a small difference between the 14 species of fish. Fish samples from Katsuwonus pelamis contained the highest concentration of $\mathrm{Mg}$ (150.4 $\mu \mathrm{g} / \mathrm{g}$ ) while Merluccius bilinearis contained the lowest $\mathrm{Mg}$ level $(137.5 \mu \mathrm{g} / \mathrm{g})$. The present values were generally consistent with ranges for other fish species [90]. According to Suseno., et al. [82], the Mg levels were between $130.6 \mu \mathrm{g} / \mathrm{g}$ in Alepocephalus bicolor and 170 and $090 \mu \mathrm{g} / \mathrm{g}$ in Setarches guentheri. Mg is essential for muscle function and prevents cardiovascular disease, osteoporosis, and certain forms of cancer [5]. The daily recommended allowance for $\mathrm{Mg}$ is $400 \mathrm{mg}$ [56].

\section{Risk assessment}

A general health risk assessments of the various heavy metals present in fish meats considered in this study indicates that consumers would have some experience of significant health risk if they only consume non-essential elements from certain species of fish available in the local markets. Among the non-essential elements assessed in this study, few fish species containing high con- 
centration of $\mathrm{Cd}$, $\mathrm{Ti}$ and $\mathrm{Pb}$ would have a relatively higher potential health risks, while the majority of the species have no health risks. Consuming more than one contaminant fish species may produce an additive effect on the body's physiological functions. $\mathrm{Pb}$ and Cd were the major health risk contributors in the study. The low levels of binding proteins in the fish muscle may account for their low concentrations of heavy metals [100]. It can therefore be concluded that levels of trace elements in fish muscle cannot necessarily represent the real impact of metal contamination. In order to assess possible contamination of fish with various elements, it is recommended that metal concentrations in other organs such as the liver, gills and kidney should be studied.

\section{Conclusions}

Essential and non-essential element composition showed small variations between 14 species of fish samples. Essential element levels of all fish species were sufficient for recommended daily allowance. The metal content is species-dependent, with some species showing high concentrations and some showing low concentrations. According to the results, mean concentrations of $\mathrm{Pb}$ in Merluccius bilinearis, Lethrinus nebulosus, Lethrinus nebulosus and Cd in Xiphias gladius and Seriola dumerili were above the maximum recommended values by the EU. High $\mathrm{Ca}$, and $\mathrm{Pb}$ contents were found in edible portions of Xiphias gladius, Seriola dumerili, Merluccius bilinearis, Lethrinus nebulosus and Lethrinus nebulosus. As, $\mathrm{Hg}$ and $\mathrm{Cr}$ concertation levels were below the maximum allowed limits in all fish samples assessed. These toxic elements of fish species are recommendable periodically by monitoring studies because regular consumption of certain fish species could pose serious human health risks.

\section{Declaration of Competing Interest}

The authors declare that they have no conflict of interest.

\section{Acknowledgment}

The Natural and Medical Sciences Research Center, University of Nizwa, Sultanate of Oman, provided the facilities to carry out the project is highly appreciated. This work was supported by a grant from the Research Council, Sultanate of Oman.

\section{Bibliography}

1. Goldhaber SB. "Trace Element Risk Assessment: Essentially Vs. Toxicity". Regulatory Toxicology and Pharmacology 38 (2003): 232-242.

2. Amiard JC., et al. "Bio accessibility of Essential and Non-Essential Metals in Commercial Shellfish from Western Europe and Asia". Food Chemistry and Toxicology 46 (2008): 2010-2022.

3. Noël L., et al. "Li, Cr, Mn, Co, Ni, Cu, $\mathrm{Zn}, \mathrm{Se}$ and Mo Levels in Foodstuffs from the Second French TDS". Food Chemistry 132 (2012): 1502-1513.

4. Lei B., et al. "Trace Elements in Animal-Based Food from Shangai Markets and Associated Human Daily Intake and Uptake Estimation Considering Bioaccessibility". Ecotoxicology and Environmental Safety 96 (2013): 160-167.

5. Özden 0., et al. "Determination of mineral composition in three commercial fish species (Solea solea, Mullus surmuletus, and Merlangius merlangus)". Environmental Monitoring and Assessment (2010).

6. Lenntech. "Lenntech water treatment and air purification holding B.V" (2020).

7. Piotrowski JK and DO Coleman. "Environmental Hazards of Heavy Metals: Summary Evaluation of Lead, Cadmium and Mercury - General Report". University of California Press: Berkeley, CA. (1980).

8. Walker CH., et al. "Principles of Ecotoxicology" 2nd ed.; Taylor and Francis Group Press: London (2001).

9. Tripathi G., et al. "Frontiers in Ecology Research". In Earthworms as Bioengineers; Antonello S.D., Ed.; Nova Publishers: New York, Chapter 7 (2007): 227.

10. Nwani CD., et al. "Assessment of Heavy Metals Concentrations in the Tissues (Gills and Muscles) of Six Commercially Important Fresh Water Fish Species of Anambra River South-East Nigeria". Asian Journal of Microbiology, Biotechnology and Environmental Sciences 11 (2009): 7-12. 
11. Hu H. "Life Support: The Environment and Human Health". In Human Health and Heavy Metals Exposure McCally M., Ed.; MIT Press: London, 2002; Chapter 4 (2002) 65-81.

12. Järup L. "Hazards of heavy metal contamination" British Medical Bulletin 68 (2003): 167-182.

13. Miedico O., et al. "Assessment of Lead, Cadmium and Mercury in Seafood Marketed in Puglia and Basilicata (Italy) by Inductively Coupled Plasma Mass Spectrometry". Food Additive Contaminants. Part B 8 (2015): 85-92.

14. Miedico O., et al. "Assessment of Heavy Metals in Bivalves Molluscs of Apulian Region: A 3-Years Control Activity of a EU Laboratory". E3S Web of Conferences 1.11006 (2013): 1-4.

15. Canlı M and G. Atll. "The relationships between heavy metal ( $\mathrm{Cd}, \mathrm{Cr}, \mathrm{Cu}, \mathrm{Fe}, \mathrm{Pb}, \mathrm{Zn}$ ) levels and the size of six Mediterranean fish species". Environmental Pollution 121 (2003): 129-136.

16. Helitz W and P. Grosch. "Schieberle, Lehrbuch der Lebensmittelchemie”. Berlin: Springer (2001) (ISBN: 3-540-41096-15).

17. Obasohan EE., et al. "A comparative assessment of the heavy metal loads in the tissues of a common catfish (Clarias gariepinus) from Ikpoba and Ogba Rivers in Benin City Nigeria". African Science 9 (2008): 13-23.

18. Vinodhini R and M Narayanan. "Heavy metal induced histopathological alterations in selected organs of the Cyprinus carpio L. (Common carp)". International Journal of Environmental. Research 3 (2009): 95-100.

19. Rajamanickam V and N Muthuswamy. "Effect of heavy metals on the level of vitamin, total lipid and glycogen reserves in the liver of common carp (Cyprinus carpio L.) Maejo". International Journal of Science and Technology 2 (2008): 391-399.

20. Georgieva E., et al. "Trace metal effects on gill epithelium of common carp Cyprinus carpio L. (cyprinidae)". Acta Zoologica Bulgarica 66 (2014): 277-282.

21. Foran JA., et al. "Risk-based consumption advice for farmed Atlantic and wild pacific salmon contaminated with dioxins and dioxin-like compounds". Environmental Health Perspective 33 (2005): 552-556.
22. Oliveira Ribeiro CA., et al. "Bioaccumulation and the effects of organochlorine pesticides PAH and heavy metals in the eel (Anguilla anguilla) at the Camargue Nature Reserve, France". Aquatic Toxicology 74 (2005): 53-69.

23. De Forest DK., et al. "Assessing metal bioaccumulation in aquatic environments: the inverse relationship between bioaccumulation factors, trophic transfer factors and exposure concentration". Aquatic Toxicology 84 (2007): 236-246.

24. Nhiwatiwa T., et al. "Metal concentrations in water, sediment and sharp tooth catfish Clarias gariepinus from three periurban rivers in the upper Manyame catchment, Zimbabwe". African Journal of Aquatic Science 36 (2011): 243-252.

25. Annabi A., et al. "Cadmium: bioaccumulation, histopathology and detoxifying mechanisms in fish". American Journal of Research Common 1 (2013): 60-79.

26. Rajeshkumar S and X. Li. "Bioaccumulation of heavy metals in fish species from the Meiliang Bay, Taihu Lake". Chinese Toxicology Reproduction 5 (2018): 288-295.

27. Egila JN and VN Daniel. "Trace metals accumulation in freshwater and sediment insects of Liberty Dam, Plateau State Nigeria". International Journal of Basic Application Science 11 (2011): 128-140.

28. Obasohan EE., et al. "Heavy metal concentrations in malapterurus electricus and chrysichthys nigrodigitatus from Ogba River in Benin City, Nigeria". African Journal of Biotechnology 5 (2006): 974-982.

29. Obasohan EE. "Heavy metals concentrations in the offal gill muscle and liver of a fresh water mudfish (Parachanna obscura) from Ogba River in Benin City, Nigeria". African Journal of Biotechnology 6 (2007): 2620-2627.

30. Millour S., et al. "Pb, $\mathrm{Hg}, \mathrm{Cd}, \mathrm{As}, \mathrm{Sb}$ and $\mathrm{Al}$ Levels in Foodstuffs from the 2nd French Total Diet Study". Food Control 126 (2011): 1787-1799.

31. Maitera ON., et al. "Determination of trace metal levels in water and sediments of River Benue in Adamawa State Nigeria". Journal of Ecological and Natural Environment 3 (2012): 149156. 
32. Tyokumbur E and T Okorie. "Toxic trace metal contamination (Arsenic, cadmium and lead) of sarotherodon melanotheron (Rupell, 1852) from alaro stream in Ibadan". Journal of Food and Nutritional Science 2 (2014): 258-261.

33. Burger J and M Gochfeld. "Mercury and selenium levels in 19 species of salt water fish from New Jersey as a function of species size, and season". Science of the Total Environment 409 (2011): 1418-1429.

34. Soto DX., et al. "Differential accumulation of mercury and other trace metals in the food web components of a reservoir impacted by chlo-alkali plant (Flix Ebro River, Spain): implications for biomonitoring”. Environmental Pollution 159 (2011): 1481-1489.

35. Korkmaz F., et al. "Radioactivity and heavy metal concentrations of some commercial fish species consumed in the Black Sea Region of Turkey". Chemosphere 87 (2012): 356-361.

36. Petrovic Z., et al. "Environmental Cd and Zn concentration in liver and kidney of European hare from different OSerbian region: age and tissue difference". Bulletin Environmental Contamination and Toxicology 90 (2013): 203-207.

37. Evans DW., et al. "Trace elements concentrations in fish livers Implications of variations with fish size in pollution monitoring". Marian Pollution Bulletin 26 (1993): 329-334.

38. Rashed MN. "Monitoring of environmental heavy metals in fish from Nasser Lake". Environmental International 27 (2001): 27-33.

39. Mustafa C and A. Guluzar. "The relationships between heavy metal ( $\mathrm{Cd} \mathrm{Cr}, \mathrm{Cu}, \mathrm{Fe}, \mathrm{Pb}, \mathrm{Zn}$ ) levels and the size of six Mediterranean fish species". Environmental Pollution 121 (2003): 29-36.

40. Yilmaz AB. "Comparison of heavy metal levels of grey mullet (Mugil cephalus L.) and sea bream (Pagellus affinis L.) caught inIskenderun Bay (Turkey) Turk". Journal of Veterinary and Animal Sciences 29 (2005): 257-262.

41. Zhao S., et al. "Role of living environments in the accumulation characteristics of heavy metals in fishes and crabs in the Yangtze River Estuary, China". Marine Pollution Bulletin 64 (2012): 1163-1171.
42. World Health Organization. Arsenic-Fact sheet $n^{\circ} 372.2012$, Geneva, Switzerland (2012).

43. European Commission. "Commission Regulation (EC) No 1881/2006 of 19 December 2006 Setting Maximum Levels for Certain Contaminants in Foodstuffs". Official Journal of the European Union 364 (2006): 5-24.

44. Toppe J., et al. "Chemical composition, mineral content and amino acid and lipid profiles in bones from various fish species". Comparative Biochemistry and Physiology Part B 146 (2007): 395-401.

45. FAO/WHO. Principles of the safety assessment of food additives and contaminants. Geneva: Food Environmental Health Criteria no. 70 (1987).

46. Cancad JED., et al. "The impact of sugar cane-burning emissions on the respiratory system of children and the elderly". Environmental Health Perspective 114 (2006): 725-729.

47. Fawole 00., et al. "Proximate and minerals composition in some selected fresh water fishes in Nigeria". International Journal of Food Safety 9 (2007): 52-55.

48. NAS-NRC. National, Drinking Water and Health, Academy of Sciences-National Research Council National Academic Press, Washington D.C. (1982).

49. Al-Busaidi M., et al. "Toxic metals in commercial marine fish in Oman with reference to national and international standards". Chemosphere 85 (2011): 67-73.

50. Mansour S and M Sidky. "Ecotoxicological Studies. 3. Heavy Metals Contaminating Water and Fish from Fayoum Governorate". Egyptian Food Chemistry 78 (2002): 15-22.

51. Hamilton MA., et al. "Determination and comparison of heavy metals in selected seafood, water, vegetation and sediments by inductively coupled plasma-optical emission spectrometry from an industrialized and pristine waterway in Southwest Louisiana". Microchemical Journal 88 (2008): 52-55

52. Saha N and MR Zaman. "Evaluation of possible health risks of heavy metals by consumption of foodstuffs available in the central market of Rajshahi City, Bangladesh". Environmental Monitoring and Assessment 185 (2012): 3867-3878. 
53. Ahmed MK., et al. "Heavy Metals in Water, Sediment and Some Fishes of Buriganga River, Bangladesh". International Journal of Environmental Research 4 (2010): 321-332.

54. Akoto 0., et al. "Concentrations and health risk assessments of heavy metals in fish from the Fosu Lagoon". International Journal of Environmental Research 8 (2014): 403-310.

55. Keskin Y., et al. "Cadmium, lead, mercury and copper in fish from the Marmara Sea, Turkey". Bulletin of Environmental contamination and Toxicology 78 (2007): 258-261.

56. Food and Drug Administration (FDA). A food labeling guide, reference values for nutrition labe (1994) (editorial revisions June 1999).

57. Regland B., et al. "Nickel Allergy is found in a Majority of Women with Chronic Fatigue Syndrome and Muscle Pain - And may be triggered by Cigarette Smoke and Dietary Nickel Intake". Journal of Chronic Fatigue Syndrome 8 (2001): 57-65.

58. Illic V., et al., "Epidemiological and pathogenic effects of nickel poisoning". Acta Medica Medianae 46 (2007): 37-44.

59. Idodo-Umeh G. "Pollutant assessments of Olomoro water bodies using Physical, Chemical and Biological indices". Ph.D Thesis, University of Benin, Benin City, Nigeria (2002): 485.

60. De Vives S., et al. "Analysis of fish samples for environmental monitoring and food safety assessment by synchrotron radiation total reflection x-ray fluorescence". Journal of Radioanalytical and Nuclear Chemistry 270 (2006): 231-236.

61. Murtala BA., et al. "Bioaccumulation of heavy metals in fish (Hydrocynus forskahlii, Hyperopisus bebe occidentallis and Clasias gariepinus) organs in downstream ogun costal waqter, Nigeria". Trans Journal of Science and Technology 2 (2012): 119-133.

62. Meche A., et al. "Determination of heavy metals by inductively coupled plasma-optical emission spectrometry in fish from the Piracicaba River in Southern Brazil". Microchemistry Journal 94 (2010): 171-174.

63. Oronsaye JAO., et al. "Trace Metals in Some Benthic Fishes of the Ikpoba River Dam, Benin City, Nigeria". African Journal of Biotechnology 9 (2010): 8860-8864.
64. Staniskiene B., et al. "Distribution of Heavy Metals in Tissues of Freshwater Fish in Lithuania”. Polish Journal of Environmental Studies 15 (2006): 585-591.

65. Doherty VF., et al. "Biomarkers of Oxidative Stress and Heavy Metal Levels as Indicators of Environmental Pollution in Some Selected Fishes in Lagos, Nigeria". American-Eurasian Journal of Agriculture and Environmental Science 7 (2010): 359-365.

66. Okoye BCO., et al. "Heavy Metals in the Lagos Lagoon Sediments". International Journal of Environmental Studies 37 (1991): 35-41.

67. Daka ER., et al. "Cadmium and lead level in some fish species from Azuabie creek in the Bonny Estuary, Nigeria". African Journal of Biotechnology 7 (2008): 63-64.

68. Oliver MA. "Soil and human health: a review". European Journal of Soil Science 48 (1997): 573-592.

69. Lee SD. "Biochemical effects of environmental pollution". Ann Arbor Science Ltd, Mich., (1977): 300.

70. Chary NS., et al. "Assessing risk of heavy metals from consuming food grown on sewage irrigated soils and food chain transfer". Ecotoxicology and Environmental Safety 69 (2008): 513-524.

71. Xue ZJ., et al. "Health risk assessment of heavy metals for edible parts of vegetables grown in sewage-irrigated soils in suburbs of Baoding City, China". Environmental Monitoring and Assessment 184 (2012): 3503-3513.

72. Farombi EO., et al. "Biomarkers of oxidative stress and heavy metals levels as indicators of environmental pollution in African catfish (Clarias gariepinus) from Ogun River". International Journal of Environmental Research and Public Health 4 (2007): 158-165.

73. Blunden S and T Wallace. "Tin in canned food: A review and understanding of occurrence and effect". Food Chemistry and Toxicology 41 (2003): 1651-1662.

74. Lendinez E., et al. "Chromium in basic foods of the Spanish diet: Seafood, cereals, vegetables, olive oils and dairy products". Science of the Total Environment 278 (2001): 183-189. 
75. Uluozlu OD., et al. "Trace metal content in nine species of fish from the Black and Aegean Seas, Turkey". Food Chemistry 104 (2007): 835-840.

76. Jordao CP., et al. "Chromium contamination in sediment, vegetation and fish caused by tanneries in the state of Minas Gerais, Brazil". Science of the Total Environment 207 (1997): $1-11$

77. Jardao CP., et al. "Chromium contamination in river waters caused by tanneries in the state of Minas Gerais, Brazil". Química Nova Journal 22 (1999): 47-52.

78. Ishaq ES., et al. "Bioaccumulation of Heavy Metalsin Fish (Tilapia zilli and Clarias gariepinus) organs from River Benue, North-Central Nigeria". Pakistan Journal of Analytical and Environmental Chemistry 12 (2011): 25-31.

79. Nwani CD., et al. "Heavy metals in fish species from lotic freshwater ecosystem at Afikpo, Nigeria". Journal of Environmental Biology 31 (2010): 595-601.

80. AOdoemelam SA. "Bioaccumulation of trace elements in fish from Oguta Lake in Nigeria". Journal of Chemistry Society of Nigeria 30 (2005): 18-20.

81. FEPA. Guideline and Standards for Environmental Pollution and Control in Nigeria. Nigeria, Federal Environmental Protection Agency (2003).

82. Suseno SH., et al. "Proximate, fatty acid and mineral composition of selected deep sea fish species from Southern Java Ocean and Western Sumatra Ocean, Indonesia”. International Food Research Journal 17 (2010): 905-914.

83. Miedico 0., et al. "Application of inductively coupled plasmamass spectrometry for trace element characterization of equine meats". International Journal of Food Properties 20 (2017): 2888-2900.

84. Ako PA and SO Salihu. "Studies on Some Major and Trace Metals in Smoked and Over-Dried Fish". Journal of Applied Sciences and Environmental Management 8 (2016): 5-9.

85. Adewoye SO and JS Omotosho. "Nutrient Composition of some freshwater fishes in Nigeria". Bioscience Research Communication 11 (1997): 333-336.
86. FAO/WHO. Vitamin and Mineral Requirements in Human Nutrition: Report of a Joint FAO/WHO Expert Consultation, 2nd ed. Food and Agriculture Organization of the United Nations, World Health Organization, Geneva, Switzerland (2004).

87. Çelik U and J Oehlenschläger. "Zinc and copper content in marine fish samples collected from the eastern Mediterranean Sea". European Journal of Food Research and Technology 220 (2005): 37-41.

88. McCluggage D. "Heavy Metal Poisoning, NCS Magazine, Published by the Bird Hospital, CO, U.S.A" (1991).

89. Bogard HR., et al. "Nutrient composition of important fish species in Bangladesh and potential contribution to recommended nutrient intakes". Journal of Food Composition Analysis 42 (2015): 120-133.

90. FAO/INFOODS. FAO/INFOODS Food Composition Database for Biodiversity Version 2.1 - BioFoodComp2.1 Food and Agriculture Organization of the United Nations, Rome, Italy (2013).

91. Dural M., et al. "Bioaccumulation of some heavy metals in different tissues of Dicentrarchus labrax L, 1758, Pagellus affinis L, 1758 and Mugil cephalus L, 1758 from the Çamlik Lagoon of the eastern cost of Mediterranean (Turkey)". Environmental Monitoring and Assessment 118 (2006): 65-74.

92. Yilmaz $\mathrm{AB}$. "Levels of heavy metals ( $\mathrm{Fe}, \mathrm{Cu}, \mathrm{Ni}, \mathrm{Cr}, \mathrm{Pb}$, and $\mathrm{Zn}$ ) in tissue of Mugil cephalus and Trachurus Mediterranean from Iskenderun Bay, Turkey". Environmental Research 92 (2003): 277-281.

93. Prasad AS. "Zinc: an overview". Nutrition 11 (1995): 93-99.

94. Pories WJ., et al. "Acceleration of wound healing in man with zinc sulphate given by mouth". Lancet 1 (1967): 121-124.

95. Ishido M., et al. "Zinc stimulates DNA synthesis during its antiapoptotic action independently with increments of an antiapoptotic protein, Bcl-2, in porcine kidney LLC-PK1 cells". Pharmacology Experimental and Therapeutic Medicine 290 (1999): 923-928.

96. Fosmire GJ. "Zinc toxicity”. American Journal of Clinical Nutrition 51 (1990): 225-227. 
97. Çelik U and J Oehlenschläger. "Determination of zinc and copper in fish samples collected from Northeast Atlantic by DPSAV". Food Chemistry 87 (2004): 343-347.

98. FAO. Compilation of legal limits for hazardous substances in fish and fishery products. FAO Fishery Circular no. 464 (1983).

99. Boyd CE and JA Davis. "Concentration of selected element and ash in Bluegill (Lepomis macrochirus) and certain other freshwater fish". Transactions of the American Fisheries Society 6 (1978): 862-867.

100. Allen-Gil SM and VG Martynov. "Heavy metals burdens in nine species of fresh water and anadromous fish from the Pechora River, northern Russia". The Science of Total Environment 160161 (1995): 653-659.

\section{Assets from publication with us}

- Prompt Acknowledgement after receiving the article

- Thorough Double blinded peer review

- Rapid Publication

- Issue of Publication Certificate

- High visibility of your Published work

Website: www.actascientific.com/

Submit Article: www.actascientific.com/submission.php

Email us: editor@actascientific.com

Contact us: +919182824667 